\title{
The Cape Cod Forest Fire Prevention Experiment"f
}

\author{
By H.A. Reynolds.
}

In the pioneer days when a forest fire occurred everybody dropped his work and went to fight it. Or as frequently happened when homes were not endangered, the fire was left to burn itself out. In any event no one received pay from the public for fighting fire. When the forests becme more valuable or the country more thickly settled some provision had to be made by which the town would bear a part of the expense of fire suppression. Later the larger political units -..- the states, the provinces and the central governments -- took up the work and great improvement was made in fire fighting apparatus and in the methods of detacting fires. Organized crews vere trained to do the actual fighting and annual appropriations for this purpose were made. More recently we have gone a step further and a re spending money for trail and road building, telephone lines, fire lines, airplane patrol and other facilities by which the fire-fighters may be able to $r$ each fires in the incipient stage. The fundamental idea underlying all of these efforts, however, has remained about the same as when the white man arrived, namely, to put the fire out after it is started, rather than to prevent its starting.

i glance at almost any compilation of statistics giving the causes of forest fires will show that fully 99 per cent of these fires are traceable directly or indirectly to human carelessness in some form. The only notable exceptions are the lightning caused fires in the higher altitudes especially in the far west. In a sense forest fires may be compared to a disease epidemic. What success would doctors have in controlling a typhoid fever outbreak, for example, if the people continued to use vater or milk from the polluted source? The polluted source of forest fires lies in that never-failing spring of humen carelessness.

The history of the efforts to cope with forest fires will disclose the fact that nearly all tho money appropriated for this purpose, both in this country and in the states, has been spent for detection and suppression. In other words we have been dealing alnost exclusively with the effect rather than the cause. Wo have besn trying to lead the mule by the tail instead of the halter rope and with somewhet similar results. It is not necessary before this audience to cite statistics to prove that the forest fire problem is far from being solved. Then we have an abnormal fire year the losses are tremendous. During 2 fow succeeding years conditions may be more nearly normal and the losses show docided reduction as compared with that year.If this improve- 
ment is continued for a time it is naturally credited to efficiency in the fire werdens organization. Then along comes another abnormal year and the losses are likely to equal or exceed those of the previous bad year. These losses in turn are taken as a new measuring: stick and so on ad infinitum. IIl tho time we are trying to cure the patient he is using water from the polluted source.

Since human carelessness is at the toot of our troubles is it not evident that our problem is psychological rather than physical -- human rather than material? The human animal like any other must be led or driven. He is led to use his common sense through education or he is driven through fear of the law.

Let us grant for the moment that the forest fire problem is basically one of public education. How should that education be applied and how can we measure its results? For many years the forestry associations and, to a limited extent, the official forestry departments have staged public educational campaigns in an effort to reduce carelessness with fire in the forests. The American Forest Week probably represents the most extensive effort of that kind. Thousands of dollars are spent in printing and circulating bulletins, magazines and press articles on the subject; posters are distributed widely; radio tallks on all phases of forostry are given by the score, as well as addresses to s chools and all sorts of civic organizations. These are the leading features of such campaigns. No one questions the desirability of such work, but when we search for the actual results in the form of reduction in fire losses they are difficult to discover. We do not know whether money spent in this work is worth 10, 50 or 100 conts on the dollar.

Since wo do not know the value in dollars and cents of public education and other means of forest fire prevontion, it has not been possible to persuade legislators that monoy in any considerable quantities should be appropriatod for that purpose. On the other hand foresters in public positions have frequently hesitated to ask for funds to be used exclusively for fire prevention and for the same reason. In most instences the funds available for forest fire work are inadequate. Should a state forester, therefore, use an appreciable part of his appropriation for prevontion and the benefits were not immediately noticeable he might bo looking for another job. Ono of the important research problems before the forester to-day is to determine the money value of public oducation and other measures such as patrol in the prevontion of forest fires. The Cape Cod Forest Fire Prevention Experiment is the first systematic attempt in the States to determine the money valye of public education and patrol in the provention of forest fires.

In this experiment which was initiated by the 
Massachusetts Forestry Association it was proposed to select an area in which the fire hazard was known to be exceptionally high and to conduct an educational campaign followed by inter.ive patrol, the local organizations for fire fighting to function as before. The costs for education, patrol and suppression were to be accurately kept for a period of three years and also the losses in acres burned over. These costs and losses were then to be compared with the costs of fighting fires and the acreage burned during the three year period prior to the beginning of the experiment.

For about fifteen years the state fire warden had been keeping records of the number of fires, the cost of suppression and the acreage bumed over in each town in the state. This enabled us to determine readily the districts of highest fire hazard. The area selected consisted of six townships on Cape Cod containing 157,000 acres of which 110,000 were covered with some form of forest growth. The townships were Bourne, Barnstable, Falmouth, Nashpee, Sandwich and Yarmouth, which were generally recognized as having the highest forest fire hazard in the state. In fact this hazard would be difficult to match anywhere east of the Rocky Mountains.

The pitch pine and the scrub oak in mixture are the predominant species and both are highly inflamianle. Fully 50 per cent of the area had been burned over at least once in the twenty years prior to the experiment, and the average annual loss during the three years immediately preceding the experiment was slightly under nine per cent of the total forest area. Large tracts vere covered with debris among which were young pines and scrub oaks -- a veritable tinder box. High winds are cormon, the snowfall is light, and forest fires have been recorded in that district every month of the year. It is not unusual to have a heavy rain one day and a forest fire the next. The soil for the most part is sandy and the vater is quickly absorbed by it. The topography is rolling and there are many ponds scattered throughout the area. On the other hand the roads leading into the interior were poor and many of them had been abandoned since the automobile came into general use. Tracts of from two to four thousand acres vithout a passable road were common. A fire occurring in one of these sections could not be reached until it hed burned out to a road because of the density of the scrub oak grouth, and by that time it was usually beyond control except by backfiring. The pitch pine and the scrub oak being almost invariably in mixture, crown fires are the rule rather than the exception unless the fire fighters reach the scene shortly after the fire starts. There is but little merchantable timoer within the district and therefore the unit of neasure of losses was taken as the acre burned over instead of the money lossos in timber destroyed.

The low value of the growth and the danger to life in fighting fires in the tangle of scrub oaks neturally led to the 
general practice of back-firing. Back-fires often became head-fires with a change of wind and more land was burned over than if no attempt had been made to stop the original fire. The blueberry grows in abundance throughout the forested district and the native is convinced that it produces more proiusely after a forest fire. This fact is crodited as the cause of many fires. Besides the land is largely owned by non-residents who pay little attention to it and hence anyone is at liberty to pick the crcp. Another fruitful cause of fires was the custom of clearing woodland by burning. One of the most important crops on the Cape is the strawberry and after a fire it is much easier to get the land under cultivation. The land selected for that purpose was usually burned over the year before whether or not it was owned at the time by the one intending to reclaim it to strawberries. A railroad traverses the area east and west, with two branch lines running north and south. It was credited with being responsible for a large part of the fire losses.

The human factor in the problem is perhaps unusual. The permanent population is about 15,000 but it is estimated that the tourists and the summer residents increase the population during the summer months to about 100,000. Cars from every state, Canada, Mexico and Hewaii have been seen on the Cape during one summer. The township of Mashpee is the old Mashpee Indian Reservation which was a terminal of the underground railroad before and during the Civil War, and inter-marriage of the two races was ccmmon. Very few whites are to be found among the present inhabitaints. Over half of the population of the township of Falmouth are Portuguese a large proportion of whom cannot speak English and this condition made the educational work difficult. This combination of soil, growth, climate and economic conditions coupled with an unusual hunan factor presented a problem that had baffled all efforts at solution. The public had come to accept forest fires as inevitable.

There are four co-operating agencies conducting the experiment; the Massachusetts Forestry Association, the State Division of Forestry, the U.S. Forest Service and the forest wardens of the six toins. The Association has cherge of the educational work, the Division of Forestry and the U.S. Forest Service direct the patrolmen and the local wardens are responsible for the suppression of the fires that occur. The U.S. Forest Service through the Clark-McNary Act is paying for half the cost of the patrol work but the supervision of the men is in charge of the State Division of Forestry.

The educational program consisted of giving talks and showing motion pictures pertaining to forestry and fire prevention to all the schools in the district and to organized groups such as women's clubs, chambers of commerce, granges, church clubs and fraternal organizations. Individuals were consulted and conferences 
were held with small groups and town officials. Literature describing the experiment and methods of fire prevention was distributed liberally; fire posters were used in all public places and large billbourds warning the public that all roads were patrolled were placed at the entrances to the area on all the main roads. Newspaper articles about the experiment were published frequently so that at the end of three months practjcaliy every man, woman and child knew about the experiment and the reasons for conducting it. This work was done from the first of January until the beginning of the fire season.

When the fire season opened two uniformed patrolmen with power of arrest and equipped with half ton Ford trucks in which were carried half a donen each of hand pumps, shovels and wire brooms, were sent into the district with instructions to cover the sections of greatest hazard. No regular routes were prescribed but picnic grounds and town dumps were visited frequently and all drivers of cars found standing along the roads were interviewed and requested to be careful of fire in the woods. Everybody was warned against throwing matches or smoking materials from their cars. Although over 8,000 people were interviewed during the first season not a single arrest was made. It was not the duty of these men to fight fires but many small ones were put out by them and they attended all the large fires acting as crew foremen. The work of the patrolmen was really educational in character since it brought them in direct contact with the local residents and especially with tourists who had not been reached previously by the lectures and other educational work. We were fortunate in securing two men especially fitted by temperament and experience for that kind of service.

Another feature of the educational programme of a very practical nature was the brushing out of old roads by which the district was divided into sections of about 160 acres, to enable the firemen to reach fires cuickly. The forestry association proposed to the towns that it would pay for half the cost of such work if the towns would meet the other half. To do this the association raised its share of the money by private subscriptions very largely within the district itself. In other words the people of the district were really paying the bill half through taxation and half through subscriptions. This plan brought the subject before the town meetings where most of the voters had a chance to discuss it. Personal solicitation of funds also had a good moral effect. These expenditures were not charged against the experiment because they would not have been made had it not been for the educational work and they were really a result of that campaign. About 175 miles have been brushed out at a cost of $\$ 30.00$ per mile.

The fire suppression work has been done by the local 
forest wardens just as before. Perhaps the incentive to make a record may have stirred them to a little greater activity but no special equipment has been acquired during the experiment except the ordinary replacements. Whatever improvement may be made in the reduction of forest fire lossea during the experiment may fairly be credited to the educational and patrol work. There is a state forest of voer 8,000 acres withịn the district and some now fire equipment has been installed there but practically all of that land had only recently been acquired after it had beon burned over a few years ago. Four fire observation towers serve the district only two of which are located in it.

There are so many variable factors entering into an experiment of this nature which to be of velue must be carried through a period of years that the results cannot be determined with mathematical accuracy. For example a local real estate beom was staged during the first year of the experiment which brought hundreds of people into the district at a time when the fire hazard was at its height. This factor was not present at any time during the three years preceding. There was one bad fire yoar during that period, however, which may off-set in part the real estate boom. But the fact that 138 fires occurred that first year as compared with 73 as the annuel average of the ghree years bofore, soems to show that this influx of people was largely responsible for the increase in number of fires. The yoar was recognized as unusually dry by all of the older residents and the rainfall during March and April, which is the most dangerous season, was nearly two inches below normal. Failure on the part of the state legislature to pass the appropriation bill for patrolman until the fire season was $\mathrm{n}$, rosulted in 500 acres being burned over by a fire started by the railroad before the patrolmen were engaged. One incendiary fire on the worst fire day of the season swept over 2500 acres. This was the largest fire of the season and its cost threatened to wrect the experiment. Practically all of the cost of the educetional work came in the first year, as vell as the cost of the equipinent for the patrolmen. With cll of these handicaps the final figuros of costs and ccres burned over a.t the end of the first year showed that although the total expense of education, patrol and suppression was 27 per cent more than the average annual cost for suppression alone during the previous three years, the losses in acres burned. over were 60 por cent less than the average of those three years.

This past year has been more fortunate although it was a bad fire year taking tho stato $2 . s$ e wholo. The expenditures this yoar for education, patrol and suppression wa.s 61.2 per cent of the average cnnual cust of suppression alone, and the losses were reduced by 88.5 por cent.

When we take the total costs and the total losses for 
the two years and compare them with the average costs and losses for a similar period under the old system we find that for 7 per cont less money spent the losses in area burned over have been reduced. by 74 per cent. The educational work is now completed and this has all been charged to the first two years. The oquipment for the patrolmon has also beon charged against theso first two yoars, and it will not only servo for the third year but should have a small salvage value at the end of the experiment. If noxt year should prove no worse than tho past year in costs and losses the final figures should show that for 20 per cent less money then was spent under the old system for supprossion alone, the fire losses will have been reduced under the now method by about 80 per cent. It is unwise, however, to predict what may happen on Cape Cod so far as forest fire is concerned.

Whatever may be the final outcome of this experiment, the results alroady accomplished are worth more than the total cost of the experiment. It is consorvativo to stato that it has brought about a decided change in public sentiment on Cape Cod not only in regard to tho fire problem, but in favour of reforestation. This little exporiment has attracted the attention of foresters and woodland ownors throughout the state and in a measure the country as a whole.

The forest warden of the adjoining town of Plymouth where conditions approximate those found in the experimental area, adopted the patrol system this past season with very satisfactory results. The aroe burned over in that township, which is the largest in the state, usually rangod from 4,000 acres to 6,000 acres in bad fire seasons and spocial appropriations had to De made for fire-fighting. Six patrolmon were omployed on ijturdays, Sundays and holidays during the fire season and only 300 acres were burnod over. What is more important from the tax-payers viewpoint is that only e. little over half of the regular appropriation was spent.

Because of the interest aroused by the experiment the Cape Cod Chember of Comierce and the Massachusetts Forestry Association appointed a joint com itteo this past summer to make a study of the forestry conditions on the Cape. The Committee worked out a 10 year programe in which the state, the towns and the private owners were each assigned specific jobs. One of its recommondations called for the application of the fire prevention methods used in the experiment to the other towns of the county, and bills are now in the mill, both in the legislature and in the town meatings to carry out this recommondation. The indications are that it will be adopted, and if so the state will furnish one patrolman for the romaining nino towns who will serve throughout the summer, and each town will co-operate by having its werdon patrol the forests during the extromoly dengerous seasons. All of the towns are also being asked to wake 2 beginning in the establishment of town forests and tho Forostry Association and the Cape 
Cod Chamber of Comnerce have each of fered to plant 5,000 trees free of charge for any town thet will create a forest of 100 acres or more.

A study has just boen comploted by the Worcs3tor County Forestry Prograrmo Committoo, which has rocom onded that tho towns of that county adopt tho firo provontion systom used on Capo cod. If a fow more successful trials of this mothod cen bo medo, it will not bo long bofore the entiro state will havo accopted the plan.

The information sought by this oxporimont will bo of valuo if not absolutely nocossary, in order that the omphasis now boing placed upon forost firo suppression by legislators and the general public, be shiftod to forostffiro prevontion. The main thing is to ostablish the fact that it is moro officiont to spend money in the provontion of fires, than for suppression aftor they are started. As with any experimont wo have had to fool our way and wo know that with more experience the costs of educational and patrol work can be roducod. Wo aro not trying to dovelope a systom so much as to prove the value of education and patrol in the provention of firos. Sinco conditions vary widely in different districts no ono formula can bo devolvod that vill fit every case, but if this oxporiment does nothing more than to encourago others to try out provontion in their own way, it will heve served a usoful purpose. \#o must find some mothod by which to rould public sentiment against carelossness with fire in the woods. As Lincoln once said "With public sontimont nothing can fail,-without it, nothing can succesd". If the old adago that "An ounce of prevention is worth a pound of cure" is truo, it certainly ought to be applied to forost fires. 